\title{
Sustainable materials and techniques in affordable high-rise buildings - A case study
}

\author{
Rajesh Kumar ${ }^{1}$, Vanita Aggarwal ${ }^{2}$ and Surinder M. Gupta ${ }^{3}$
}

${ }^{1}$ Ph.D. Research Scholar, M.M. Engineering College, M.M (Deemed to be University), Mullana, Ambala, Haryana, India-133207 ${ }^{2}$ Professor, Civil Engineering Department, M.M. Engineering College, M.M (Deemed to be University), Mullana, Ambala, Haryana, India-133207

${ }^{3}$ Professor, Department of Civil Engineering, NIT Kurukshetra, Haryana, India -136119

\begin{abstract}
Sustainability is a crucial issue since the last decade as the building sector, directly or indirectly cause a considerable portion of the annual environmental deterioration. Due to increase in houses' demand, leading to consumption of more resources, energy and raw materials which are directly responsible for the rise in carbon content in air and which are harmful to human health and environment. To overcome these various environmental impacts, we need to build with more sustainable materials which will reduce the impacts on environment. Design of a building is essential and it becomes crucial when we talk about affordable housing.[1]India needs not only affordable housing, but also homes that are energy efficient and designed using sustainable techniques. The green buildings design should thus begin with the use and selection of eco-friendly materials with related or better features than traditional building materials.[2]The paper aims at sustainable development in affordable high-rise buildings with fast track techniques and procedures to reduce overall time and cost of the project.
\end{abstract}

\section{Introduction}

The building construction industry is a vital element of any economy but has a significant adverse impact also on the environment. Construction is one of the largest users of material resources, energy and water, and it is a formidable polluter by virtue of its size. Buildings have a tremendous impact on the environment, consuming virtually $70 \%$ of electricity and $12 \%$ of potable water, using about $40 \%$ of natural resources extracted in industrialized nations, and producing between $45 \%$ and $65 \%$ of the waste disposed in the landfills.[2] The selections of materials and layouts are necessary for the general sustainability. The research community worldwide has carried out considerable initiatives, in order to find alternative sustainable building materials and low technology methods, which result in a more sustainable and affordable construction needed today. Adoption of green building materials is an excellent approach to meet this target. The construction materials which have minimum environmental burdens are useful in the sustainable development of a country. Green building can be described as people with comfortable, healthy and safe

\footnotetext{
${ }^{1} \mathrm{Ph} . D$. Research Scholar, e-mail: raj1rathee@gmail.com

${ }^{2}$ Professor\& Head, e-mail: aggarwal_vanita@rediffmail.com

${ }^{3}$ Professor, e-mail: sm_gupta85@rediffmail.com
}

living, working and activities of the space, while the building full life cycle (construction planning, design, construction, material production, operation and maintenance) process to achieve efficient use of resources (energy, water, materials) with minimum impact on the environment of buildings, also known as sustainable building. The Green building uses building materials which are locally available and are sustainable, energy efficient and durable also. Looking the local material availability, lime is one of such material which reduces the internal room temperatures by $4^{\circ} \mathrm{C}$ to $5^{\circ} \mathrm{C}$ as compare to cement in plastering work. [3]

\section{Sustainable Development of Construction Industry}

The use of sustainable building materials, which is the most effective way for the construction industry to contribute to protect the environment, has become the main possible solution to minimize the environmental impact and achieve sustainable development. 


\subsection{Sustainable Building Objectives:}

These objectives include:

1. Resourceconservation

2. Cost efficiency and

3. Design for Human adaptation

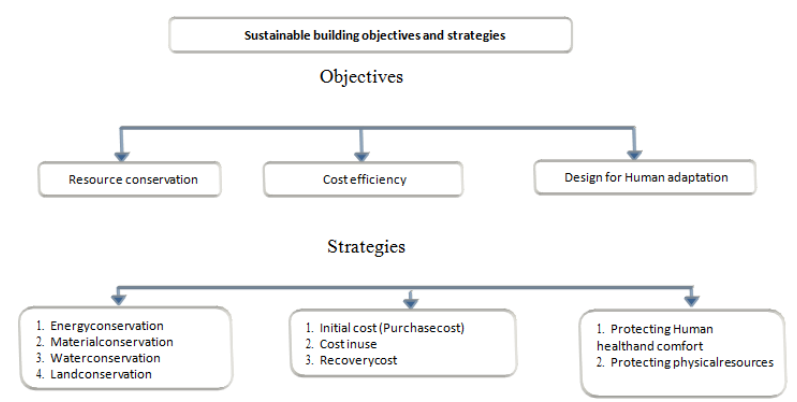

Fig 1. Framework for implementing sustainability in building construction. [4]

\subsection{Sustainable Building Materials Life Cycles}

A material's life cycle could be well organized into three stages, Pre-Building, Building, and Post-Building. [2]

\section{A. Pre-building phase}

The Pre-Building stage details the production and delivery process of a material up to, but not including, the point of installation. This consists of finding raw materials in nature as well as extracting, manufacturing, packaging, and transportation to a building site. This stage of pre-building phase has the most possibility of creating environmental destruction.

\section{B. Building phase}

This stage begins at the point of the material's assembly into a structure, involves the maintenance and repair of the material, and goes all over the lifetime of the material as part of the building. The material waste generated on a building construction site can be considerable.

\section{Post-building phase}

A material could possibly be recycled in its entirety, have its elements reused back into other goods, or perhaps be thrown away at this stage. The demolition of buildings and clearance of the resulting waste has a substantial environmental cost.

\subsection{Pre-requisites for Sustainable Building Construction Development:}

- Making a building sustainable begins at the planning stage. After the construction period is over, it is challenging to make a building green completely.
- A residential building should be located in a centralized place so that inhabitants can use public transport and less or no fossil fuel run vehicles. Also, Energy utilization should be optimum.

- Discharge of water should be zero. All waste water should be treated biologically and recycled. Specification of structure should allow for harvesting the rain water. Grey water should be used for flushing and gardening.

- Recycled materials should be used to a greater extent as maximum as can.

- Instead of bricks, aerated concrete blocks should be used for better insulation and heat rejection.

- Roof insulation should be done with clay rather than chemicals.

\section{Methodology}

\subsection{Materials}

The sustainable building materials which can be selected looking in to their local availability, benefits, cost and durability are Pozzolana materials, recycled steel reinforcement, ferro cement and precast components, bricks from coal washery rejects, building blocks from mines and industrial waste, calcium silicate plaster, micro concrete roofing tiles, clay tiles, low voc paints, adhesives, sealants and composite wood products, use of recycled content in roads and pavements, gypsum board, tiles, plaster, blocks, gypsum plaster fibre jute/sisal and glass fibre composites.

\subsubsection{Lime}

Lime is one of the common materials which replaces cement content in building construction. By absorbing the carbon and emitting oxygen in the atmosphere, it gives the good air quality.

\subsubsection{Eco-Friendly Tiles}

An Eco-friendly tile replaces the traditional flooring and uses less energy in their production comparatively. It is cheap in cost as compared to the conventional tile. These tiles also improve performance of indoor environment quality.

\subsubsection{Coloured Lime Plaster}

Colored lime plaster as paint reduces the painting for whole structural life. It is water proof, washable and maintenance free. Its shine and glossiness increase as the Life cycle passes. It gives better aesthetics look than traditional painting work. 


\subsubsection{Reflectasol Glass}

Reflectasol glass keeps the inner temperature cool even in hotter summers which reduce the energy consumption. This glass reduces the solar heat gain but allows the optimum lighting throughout the day. It is a good resistant of U.V rays which reduces the cause of occupant'sskin retention. It also gives better privacy comparative to the normal clear glass.[3]

\section{Technology}

\subsection{Aluminum Formwork}

Aluminum formwork technology is the technique which used majorly in current construction scenario; it is simple and easily adaptable. This formwork is made up of aluminum, it is light weight and can be easily carried manually. This formwork technique concern to a monolithic construction, where columns, walls, and slab are cast in one continuous pour. This technology involves initial high investment for manufacturing of forms but due to its higher repeatability than the conventional formwork (around 250) it is more feasible in terms of viability and time.[6]

The Aluminum formwork technique usually follows 4 step cycle: -

1. First, erect vertical formwork and reinforcement bars for entire or part of floor.

2. Then, erect other side of vertical formwork and formwork for the floor at horizontally.

3. Reinforce and conduits the floor slabs and concreting of walls and slabs is done.

4. Remove vertical formwork panel after 24 hours of concreting.

\subsection{Self-Compacting Concrete}

Another way to improve ecological performance ofconcrete is to produce innovative types of concrete which will be more durable or require lower laborcost and energy consumption for its manufacturing and placing. One of latest innovations in the field of civil engineering materials is Self-compacting concrete (SCC). SCC does not require vibration for placingand compaction. It is able to flow under its own weight, completely filling formwork and achievingfull compaction. The use of self-compacting concrete (SCC) can be a major contribution to reach a better sustainable development, namely by incorporating significant quantities of sub-products of other industries and recycled materials in its composition, and by potentially increasing the structures durability which will lead to longer life cycles. [7]

\subsection{Rainwater Harvesting}

Rainwater harvesting systems to supply water for some, or all of the water needs, can reduce the dependence on municipally treated water. Stormwater runoff can reduce from a property by rainwater harvesting. It is an excellent source of water for landscape and plant irrigation since it is chemicals free such as fluoride and chloramines (chlorine). [9]

\subsection{Passive Building Design}

Passive solar building designs naturally use the sun's energy for free of charge heating, cooling and daylighting. This design also reduces the need to consume energy from other sources and provides a comfortable environment inside. This method allows for the walls, windows and floors of buildings to collect the sun's energy during winter months, and reject it during the summer months.

\subsection{Active Solar Technologies}

Active solar technologies are used to directly convert solar energy into another form of useful energy, such as heat conversion or electricity. Active solar technologies are described below.

- Solar heating and cooling produce heat from the sun's thermal energy to provide hot water, heating and cooling, and pool heating. Solar Photovoltaic (PV) energy directly converts the sun's light into energy by solar PV panels. Smaller-scale PV systems are commonly seen on rooftops or buildings, while larger-scale solar PV systems are associated with photovoltaic power stations, or solar parks. A solar PV system consists of one or more PV panels, electrical interconnections, a DC/AC power converter (or inverter), and then mounting components.[8]

\section{Case Study}

To study and analyze the effectiveness of these materials and techniques and compare these techniques, a case study was undertaken.

Project: Affordable High-rise Building construction projects for MAHIRA HOMES [10]

Location: Mahira Homes, Sec-103\& Sec 68,

Gurugram [11]

Developer: MahiraBuildtech Pvt. Ltd

Project Duration: 18 months

Builtup Area: 751344 sft and $1305000 \mathrm{sft}$

respectively

No. of Flats: 820 Flats and 1497 Flats respectively

Buildings under study are $\mathrm{G}+14 / 19$ constructed as per GRIHA guidelines for sustainable development in affordable housing using by Passive design of building for Daylight and Ventilation, Aluminum formwork technique, Rainwater harvesting, top soil preservation, pollution free working environment, using sustainable building materials experimental investigation was carried out only for superstructure. The time and cost impact all over the project have not been exceeded due 
to implementation of sustainable development techniques. Although, it reduces the cost in some cases and increase the life cycle of the buildings. Using Sewage Treated Plant (STP) water for construction purposes, really save the ground water and better optimization of waste water. Segregation of construction waste and recycle of that waste reduces the cost and quantum of waste as well at site.

The First Affordable High-rise Building Projects who registered for 5-star rating under GRIHA among all over the India and get the first pre-certificate of 5-star rating based on the submission and assessment.

\section{Results}

After studying detailed plans and procedures, determining the resources required, scheduling the activities and preparing the approximate estimation and comparing one of the techniques from above mentioned i.e. conventional formwork technique with respect to Aluminum formwork technique, the results are presented in Table:

Table 1: Comparison of Conventional Formwork with respect to Aluminum formwork.

$\left.\begin{array}{|l|c|c|}\hline \text { Criteria } & \begin{array}{c}\text { Aluminum } \\ \text { Formwork } \\ \text { Technique }\end{array} & \begin{array}{c}\text { Conventional } \\ \text { Formwork } \\ \text { Technique }\end{array} \\ \hline \text { Steel Saving } & 10 \% & - \\ \hline \text { Brick } & \text { No } & \text { Required 20-30\% } \\ \hline \text { Wall Panel } & \text { Not required } & \text { Required } \\ \hline \begin{array}{l}\text { Plaster } \\ \text { Requirement }\end{array} & \text { Not required } & \text { Required } \\ \hline \text { Time Saving } & \begin{array}{c}\text { Approx. } 65 \% \text { as } \\ \text { per 7 days slab } \\ \text { cycle }\end{array} & 21 \text { days slab cycle } \\ \hline \begin{array}{l}\text { Initial } \\ \text { Investment }\end{array} & \text { High } & \text { Low } \\ \hline \text { Feasibility } & \text { Yes } & \text { No } \\ \hline \text { Labour Cost } & \text { Less required } & \text { More required } \\ \hline \begin{array}{l}\text { Suitability of } \\ \text { HighRise }\end{array} & \text { Yes } & \text { Tough } \\ \hline \text { Environmental } \\ \text { Concern }\end{array}\right)$

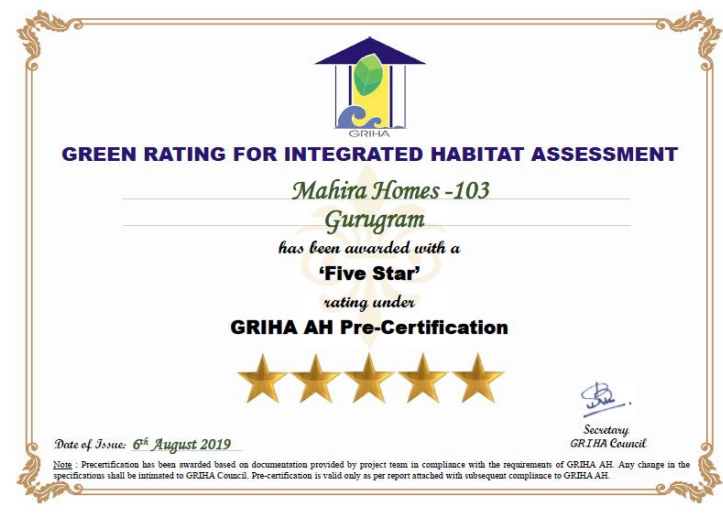

It is found that the construction building implementing all the necessary consideration to make it sustainable isas follows:

- $100 \%$ on-site sewage treatment.

- $100 \%$ waste management by using the waste to generate organic manure.

- $30-40 \%$ savings in energy and $20-30 \%$ savings in water.

- A 12,000 tone $\mathrm{CO}_{2}$ reduction per annum for every one million sq. $\mathrm{ft}$ of constructed space.

\section{Conclusion}

From the present case study, the following conclusions can be safely drawn-

- Sustainable building materials are the materials which are domestically produced and sourced which decreases transportation costs and $\mathrm{CO}_{2}$ emissions, they could consist of reused materials, they are thermally effective, and they need less energy than conventional materials.

- The construction sector, directly or indirectly creating a substantial portion of the environmental destruction, may take up the obligation to promote sustainable development. Green construction material reduces side effects on environment. The relationship between environmental management, economic development, and human health is a complicated process, affecting both the quality and sustainability of the society in which we all live.

- Green building decrease building's embodies energy through efficient design, use of recycled and local materials and recycling construction waste. Sustainable building design also reduces energy consumption over its lifetime. Skylight and strategically placing windows can eliminate the need for electrical lighting during the day. Good quality insulation reduces temperature regulation costs in both winter and summer. Green building consumes less water as compared to traditional building. 


\section{References}

1. N. Singh, Journal of Indian Building Congress, 23,97 (2016).

2. Umar, U. A., Khamidi, M. F. \& Tukur Hassan , Management in Construction Research Association conference, Malaysia (2012).

3. A. B. Mokal, A. I. Shaikh, International Journal of Application or Innovation in Engineering \& Management, 4, 244 (2015).

4. P.O. Akadiri, Buildings 2, 126 (2012)

5. Song, Y., Zhang, H., IOP Conference Series: Materials Science and Engineering, 452, (2018)

6. M. Sandeep, International Journal of Intellectual Advancements and Research in Engineering Computations, 6, 1297 (2018).

7. P. Aggarwal, Leonardo Electronic Journal of Practices and Technologies, 12, 15 (2008).

8. A. Chel, G. Kaushik, Alexandria Engineering Journal, 57, 655 (2017).

9. GRIHA. Griha for Affordable Housing. 2017, https://affordablehousingonline.com

10. Mahira Homes, Sec -68, Gurugram (Haryana), India

11. Mahira Homes, Sec 103, Gurugram (Haryana), India 